\title{
GENETIC ANALYSIS OF ESCHERICHIA COLI STRAINS CARRYING ENTEROPATHOGENIC ESCHERICHIA COLI (EPEC) MARKERS, ISOLATED FROM CHILDREN IN RIO DE JANEIRO CITY, BRAZIL
}

\author{
Adriana Hamond Regua-Mangia ${ }^{1 *}$; Tânia Aparecida Tardelli Gomes ${ }^{2}$; João Ramos Costa Andrade ${ }^{3}$; Mônica Aparecida

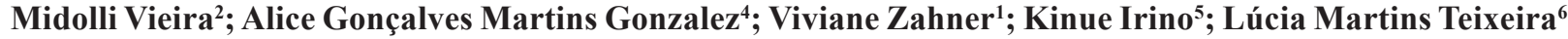 \\ ${ }^{1}$ Fundação Oswaldo Cruz, Rio de Janeiro, RJ, Brasil. ${ }^{2}$ Universidade Federal de São Paulo, São Paulo, SP, Brasil. ${ }^{3}$ Universidade \\ Estadual do Rio de Janeiro, Rio de Janeiro, RJ, Brasil. ${ }^{4}$ Universidade Federal Fluminense, Rio de Janeiro, RJ, Brasil. ${ }^{5}$ Instituto \\ Adolfo Lutz, São Paulo, SP, Brasil. ${ }^{6}$ Universidade Federal do Rio de Janeiro, Rio de Janeiro, RJ, Brasil.
}

This paper corresponds to an "extended abstract" selected for oral presentation in the $22^{\text {nd }}$ Brazilian Congress of Microbiology, held in Florianópolis, SC, Brazil, in November 17-20, 2003

\begin{abstract}
In the present study, 47 enteropathogenic Escherichia coli strains identified according to serotyping, presence of eae, $b f p$ and EAF sequences, adherence phenotype and ability to induce attaching-effacing lesions were analyzed by pulsed-field gel electrophoresis (PFGE), multilocus enzyme electrophoresis (MLEE), and the presence of LEE genes (eae, esp A, esp B, tir) as well as the respective alleles. Amplification of LEE genes subtypes revealed 18 different pathotypes. Typing of the eae gene showed that most strains contained nontypable intimin (42\%) followed by $\beta(35 \%)$, $\gamma$ and $\alpha$ genes (12\% each). PFGE analysis revealed a variable degree of polymorphism among isolates and, in general, no clear correlation was observed among PFGE profiles and the virulence markers identified. Otherwise, grouping based on MLEE analysis showed a close association between eae allele and clonal cluster distribution leading us to indicate the eae profile as a promising marker to establish relatedness among such microorganisms.
\end{abstract}

Key words: enteropathogenic Escherichia coli, genetic diversity, virulence markers.

\section{INTRODUCTION}

Enteropathogenic Escherichia coli (EPEC) is a diarrheagenic human pathogen and remains a leading cause of childhood diarrhea in several developing countries (1). EPEC exhibits a localized adherence (LA) pattern and forms characteristic lesions on infected mammalian cells called attaching-effacing lesions (AE). LA is associated with the presence of the EPEC adherence factor (EAF) plasmid, which carries the EAF probe sequence, the $b f p$ genes and the per regulatory locus. The $35 \mathrm{~Kb}$ chromosomal pathogenicity island, called the locus of enterocyte effacement (LEE), contains genes critical for pedestal formation (A/E lesion). LEE encodes a type III protein secretion system, the translocated proteins
(Esp proteins), the adhesive protein intimin and the translocated intimin receptor (Tir). Genetic characterization of the $\mathrm{A} / \mathrm{E}$ virulence genes revealed the presence of constant and variable regions which comprise specific LEE pathotypes that seem to be closely related to strain source and serogrouping (2). The assessment of the clonal structure and genetic relationship among E. coli strains carrying EPEC virulence markers revealed that specific evolutionary lineages differ in the LEE insertion sites on the E. coli chromosome (3), carry distinct eae alleles $(4,5)$ as well as exhibit distinct phenotypic properties. In the present study, we describe the genetic characteristics of $E$. coli strains that carried EPEC virulence markers according to LEE alleles, pulsed-field gel electrophoresis and multilocus enzyme electrophoresis.

*Corresponding author. Mailing address: Departamento de Ciências Biológicas. Escola Nacional de Saúde Pública. Fundação Oswaldo Cruz. Rua Leopoldo Bulhões, 1480. 21041-210, Rio de Janeiro, RJ, Brasil. Tel.: (+5521) 2564-8985. E-mail: regua@ensp.fiocruz.br 


\section{MATERIALS AND METHODS}

The 47 E. coli isolates used in this study were recovered from children with (case) and without (control) diarrhea at the Hospital Pediátrico Jesus in Rio de Janeiro city and previously characterized. E. coli strains consisted mostly of $\mathrm{O}-$ and $\mathrm{H}-$ typable strains arranged into different $\mathrm{O}: \mathrm{H}$ combinations $(\mathrm{O} 11: \mathrm{H}-$; $\mathrm{O} 15: \mathrm{H} 16, \mathrm{H} 18 ; \mathrm{O} 29: \mathrm{H} 40 ; \mathrm{O} 51: \mathrm{H}-; \mathrm{O} 61: \mathrm{H} 2 ; \mathrm{O} 80: \mathrm{H} 26 ; \mathrm{O} 101: \mathrm{H}-;$ O111:H2,H27; O118:HNT; O128:H-; O129:H11;O142:H34; O145:H45,H-; O157:H-; O162:H33 and ONT:H8,H10,H19). 57\% exhibited a LA-like pattern, $21 \%$ expressed a non-characteristic adherence and $22 \%$ showed LA. FAS-positive isolates corresponded to $86 \%, 75 \%$ and $67 \%$ of the $E$. coli that expressed LAL, LA and NC patterns, respectively. 58\% carried the eae gene only, $34 \%$ also possessed the $b f p A$ and/or EAF sequences. For MLEE analysis, bacterial cells were characterized according to the allelic variation of 10 enzyme-encoding loci as described (6): aconitase, adenylate kinase, alcohol dehydrogenase, glucose-6-phosphate, glucose-6-phosphate dehydrogenase, glucose phosphate isomerase, isocitrate dehydrogenase, malate dehydrogenase, phenylalanyl-leucine peptidase and phosphoglucomutase. Numerical analysis was performed using the NTSYS-PC Program. Isolates that lacked detectable enzyme activity were designated a null allele state at the locus in analysis. The detection of the eae, tir and esp genes variants was carried out by multiplex PCR reactions according to previous recommendations (2). For PFGE analysis, plugs containing bacterial chromosomal DNA were digested with $X b a \mathrm{I}$ and processed as previously described (7) with some modifications. Electrophoretic parameters were: pulse time ranging from 5 to $50 \mathrm{~s}$ for $23 \mathrm{~h}$ at $11^{\circ} \mathrm{C}$, in a voltage gradient of $6 \mathrm{~V} / \mathrm{cm}$. PFGE profiles were compared by visual and automated analysis by using the Molecular Analyst Fingerprint Plus software (Bio-Rad).

\section{RESULTS}

Typing based on the eae, tir, esp $\mathrm{A}$ and $e s p \mathrm{~B}$ genes revealed 18 different LEE pathotypes arranged into several gene combinations. Most strains isolated from children with diarrhea contained nontypable intimin genes (42\%) followed by $\beta(35 \%)$, $\gamma$ and $\alpha$ genes (12\% each). For the remaining LEE sequences investigated, nontypable tir (42\%), esp $\mathrm{A}_{\alpha}(33 \%)$ and $\operatorname{esp} \mathrm{B}_{\alpha}$ (41\%) genes were the most frequent variants. E. coli strains isolated from the control group possessed only the $e a e_{\beta}$ and nontypable intimin genes and the $t_{i}, \operatorname{esp} \mathrm{A}$ ( $\beta$ and $\alpha$ variants) and $\operatorname{esp} \mathrm{B}(\alpha, \beta, \gamma$ variants) gene variants. PFGE typing using

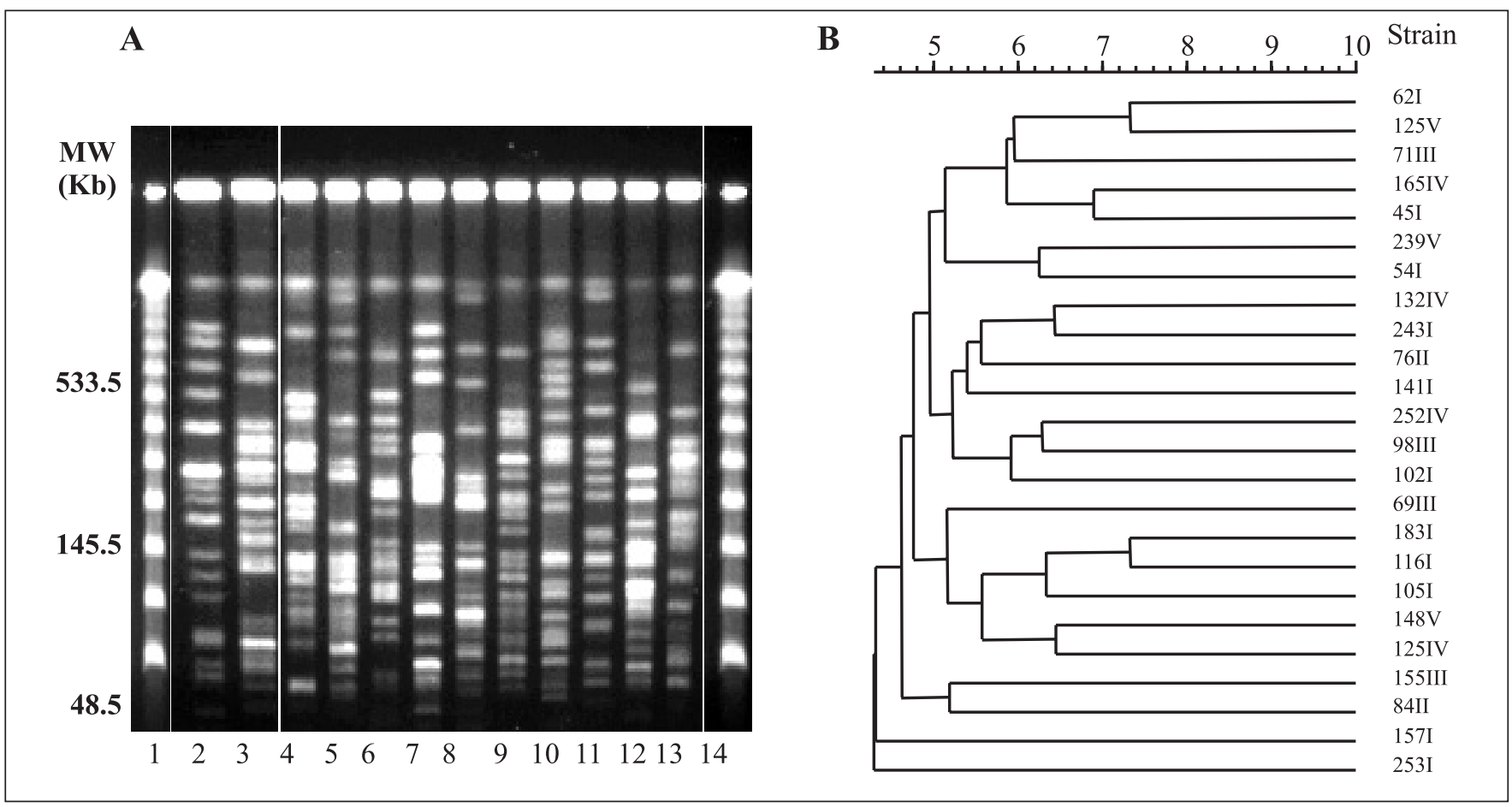

Figure 1. A- Representative PFGE profiles of XbaI digested DNA of E. coli strains carrying enteropathogenic Escherichia coli (EPEC) genetic markers; B- Dendrogram resulting from computer-assisted analysis based on PFGE profiles similarities. Lanes 1 and 14- (DNA ladder ranging from 48.5 to 1018.5 Kb); Lane2-132IV; Lane3-141I; Lane4-148V; Lane5- 239V; Lane6-155III; Lane7157I; Lane8-165IV; Lane9-183I; Lane10-243I; Lane11- 252IV-; Lane12-253I; Lane13-71II.) 
XbaI endonuclease (Fig. 1) generated 24 distinct electrophoretic profiles composed by 10-18 polymorphic bands and showed intra and inter-serotype variations providing clearly distinguishable electrophoretic profiles. Closer relatedness was observed among $E$. coli strains sharing $\mathrm{H}$ antigens but no clear correlation was observed with the virulence markers investigated.

MLEE results revealed that all 10 enzyme loci studied were polymorphic, and the number of alleles ranged from 2 for phosphoglucomutase to 6 for glucose-6-phosphate dehydrogenase. Allele profiles revealed 19 distinct ETs. Sixteen ETs were represented by single serotypes. MLEE clustering (Fig. 2) defined three main groups but no significant clustering among strains was related to serogroup, serotype or virulence properties. Otherwise, strains belonging to the related clonal groups shared the eae alleles.

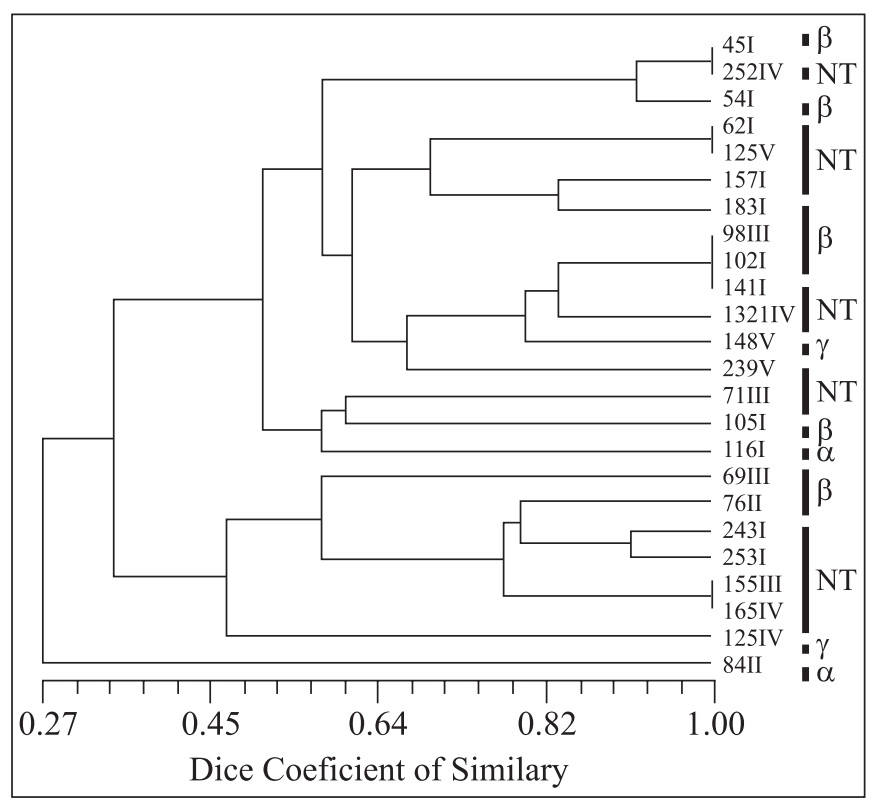

Figure 2. Genetic relationship of multilocus enzyme genotype and eae allele distribution among E. coli strains carrying enteropathogenic Escherichia coli (EPEC) genetic markers.

\section{DISCUSSION}

In the present study, the majority of the E. coli isolates consisted of $\mathrm{O}$ - and $\mathrm{H}$-typable strains belonging to non-classical EPEC groups that carried eae only or eae and $b f p A$, exhibited localized adherence-like phenotype and showed ability to aggregate actin. The limited range of strains belonging to a specific serogroup did not allow us to establish any correlation between LEE pathotypes, $\mathrm{O}: \mathrm{H}$ antigens as well as diarrheal disease. Our results corroborate with previous observations by detecting $E$. coli strains presenting atypical properties associated with $\beta$ and $\gamma$ intimins (8). However, the majority of strains had nontypable intimin alleles, suggesting that they may belong to intimin types not investigated in the present work or may correspond to new yet to be described intimin types. Such observation may represent a further evidence of differences between atypical and typical strains. The high level of polymorphism detected by PFGE and MLEE analysis probably reflected the variability of serogroups or serotypes in the population studied. Despite the diversity observed, a correlation between clonal groups and intimin type was noticed leading us to recognize its potential as a promising marker for the establishment of the relatedness among these microorganisms and for the detection of the emergence of EPEC pathogenic subgroups or new diarrheagenic categories as well as for the elucidation of specific virulence potential.

\section{ACKNOWLEDGEMENTS}

We thank Carlos Ausberto Bonetti de Souza for technical assistance. This work was supported, in part, by grant from Fundação Oswaldo Cruz-RJ, Brazil (PAPES 2, No-250.250.339), Fundação de Amparo à Pesquisa do Estado do Rio de Janeiro (FAPERJ) and Ministério da Ciência e Tecnologia (MCT/ PRONEX).

\section{RESUMO}

\section{Análise genética de amostras de Escherichia coli carreadoras de marcadores da Escherichia coli Enteropatogênica (EPEC), isoladas de crianças na cidade do Rio de Janeiro, Brasil}

No presente estudo, 47 amostras enteropatogênicas de Escherichia coli, previamente caracterizadas pelo sorotipo, fenótipo de aderência, habilidade de induzir a formação da lesão histopatológica e presença das seqüências genéticas eae, $b f p$ e EAF, foram analisadas de acordo com o perfil de fragmentação do DNA cromossômico pela técnica de eletroforese em campo pulsado (PFGE), as variantes isoenzimáticas através da eletroforese de isoenzimas (MLEE) e a presença de seqüências específicas da região LEE (eae, $\operatorname{esp} \mathrm{A}, \operatorname{esp} \mathrm{B}$, tir) e respectivos alelos. A amplificação destas seqüências mostrou a presença de 18 padrões genéticos distintos. A tipagem do gene eae revelou que a maior parte das amostras apresentou intimina não-tipável (42\%) seguida

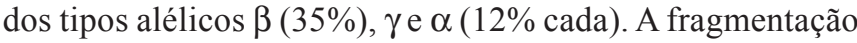
do DNA cromossômico detectou um elevado polimorfismo genético entre as amostras estudadas e não foi observada uma correlação com os marcadores de virulência investigados. Por outro lado, a análise das variantes isoenzimáticas sugeriu uma distribuição clonal específica de variantes genéticas do 
locus eae, o que nos leva a indicar a sua utilização como um marcador promissor para definir as relações genéticas neste grupo de microrganismos.

Palavras-chave: Escherichia coli enteropatogênica, diversidade genética, marcadores de virulência.

\section{REFERENCES}

1. Nataro, J.P.; Kaper, J.B. Diarrheagenic Escherichia coli. Clin. Microbiol. Rev., 11:142-201, 1998.

2. China, B.; Gollaux, F.; Pirson, V.; Maini, J. Comparison of eae, tir, $\operatorname{esp} \mathrm{A}$ and $\operatorname{esp} \mathrm{B}$ genes of bovine and human attaching and effacing Escherichia coli by multiplex polymerase chain reaction. FEMS Microbiol. Lett., 78:177-182, 1999.

3. Wieler, L.H.; McDaniel, T.K.; Whittam, T.S.; Kaper, J.B. Insertion site of the locus of enterocyte effacement in enteropathogenic and enterohemorrhagic Escherichia coli differs in relation to the clonal phylogeny of strains. FEMS Microbiol. Lett., 156:49-53, 1997.
4. Adu-Bobie, J.; Frankel, G.; Bain, C.; Gonçalves, A.G.; Trabulsi, L.R.; Douce, G.; Knutton, S.; Dougan, G. Detection of intimins $\alpha$, $\beta, \gamma$ and $\delta$ four intimin derivatives expressed by attaching and effacing microbial pathogens. J. Clin. Microbiol., 36:662-668, 1998.

5. McGraw, E.A.; Li, J.; Selander, R.K.; Whittam, T.S. Molecular evolution and mosaic structure of $\alpha, \beta$ and $\gamma$ intimins of pathogenic Escherichia coli. Mol. Evol. Biol., 16:12-22, 1999.

6. Oswald, E.; Schmidt, H.; Morabito, S.; Karch, H.; Marchés, O.; Capriolo, A. Typing of intimin genes in human and animal enterohemorrhagic and enteropathogenic Escherichia coli: characterization of a new intimin variant. Infect. Immun., 68:6471, 2000.

7. Pupo, G.M.; Karaolis, D.K.R.; Lan, R.; Reeves, P.R. Evolutionary relationships among pathogenic and nonpathogenic Escherichia coli strains inferred from multilocus enzyme electrophoresis and $m d h$ sequence Studies. Infect. Immun., 65:2685-2692, 1997.

8. Teixeira, L.M.; Carvalho, M.G.S.; Merquior, V.L.C.; Steigerwalt, A.G.; Brenner, D.J.; Facklam, R.R. Phenotypic and genotypic characterization of Vagococcus fluvialis, including strains isolated from human sources. J. Clin. Microbiol., 35:2778-2781, 1997. 